\title{
The Effect of Using Pumice Powder and Plasticizer on Physico-Mechanical and Thermal Properties of Cement-Bonded Particleboards
}

\section{Utjecaj praha plovućca i plastifikatora na fizičko-mehanička i toplinska svojstva cementom vezanih iverica}

Original scientific paper • Izvorni znanstveni rad Received-prispjelo: 17. 2. 2020.

Accepted-prihvaćeno: 14. 1. 2021.

UDK: $630 * 863.21 ; 630 * 812.141 ; 630 * 812.701$

https://doi.org/10.5552/drvind.2021.2008

(C) 2021 by the author(s). Licensee Faculty of Forestry, University of Zagreb. This article is an open access article distributed under the terms and conditions of the Creative Commons Attribution (CC BY 4.0) license.

\begin{abstract}
In this study, the effect of using pumice powder and plasticizer on some properties of cementbonded particleboards (CBPBs) was investigated. Therefore, CBPBs were produced using $0 \%, 10 \%, 20 \%$ and $30 \%$ pumice powder and $0 \%, 0.4 \%, 0.8 \%, 1.2 \%$ plasticizer. Based on test results, it was found that using pumice powder had an important positive effect on water absorption and thickness swelling, but no effect on density. The amount of thickness swelling decreased by $15 \%$ with the use of $30 \%$ pumice powder. The modulus of elasticity and internal bond strength were generally increased by $20 \%$ with the use of pumice powder, while modulus of rupture and thermal insulation properties were decreased. The use of $0.4 \%$ and $0.8 \%$ plasticizers positively affected the properties of board properties. The use of plasticizer had a positive effect on thermal properties. The thermal conductivity values decreased by $18 \%$ as the amount of plasticizer increased to $1.2 \%$. In this regard, the use of plasticizers in CBPBs production is an option in terms of improving thermal properties.
\end{abstract}

Keywords: cement-bonded particleboard (CBPBs); pumice; plasticizer; physical and mechanical properties; thermal conductivity

SAŽETAK • U radu je opisano istraživanje utjecaja praha plovućca i plastifikatora na neka svojstva cementom vezanih iverica (CBPB). Stoga su CBPB proizvedeni upotrebom 0, 10, 20 i 30 \% praha plovućca te 0, 0,4, 0,8 i 1,2 $\%$ plastifikatora. Na temelju rezultata ispitivanja utvrđeno je da je prah plovućca imao znatan pozitivni učinak na upijanje vode i debljinsko bubrenje ploča, dok se gustoća ploča nije mijenjala. Upotrebom $30 \%$ praha plovućca debljinsko se bubrenje ploča smanjilo za $15 \%$. Modul elastičnosti i međuslojna čvrstoća proizvedenih ploča uz upo-

\footnotetext{
${ }^{1}$ Author is researcher at Karadeniz Technical University, Arsin Vocational School, Department of Material and Material Processing Technologies, Trabzon, Turkey.

2 Author is researcher at Karadeniz Technical University, Faculty of Forestry, Department of Forest Engineering, Trabzon, Turkey.

${ }^{3}$ Author is researcher at Artvin Coruh University, Artvin Vocational School, Department of Material and Material Processing Technologies, Artvin, Turkey.
} 
trebu praha plovućca povećali su se za $20 \%$, dok su se modul loma i toplinska izolacija smanjili. Upotreba 0,4 i 0,8 $\%$ plastifikatora pozitivno je utjecala na svojstva ploča. Primjena plastifikatora pozitivno je utjecala i na toplinska svojstva ploča. Pri povećanju količine plastifikatora na 1,2\%, vrijednosti toplinske vodljivosti smanjile su se za $18 \%$. Stoga je upotreba plastifikatora u proizvodnji CBPB-a jedna od opcija za poboljšanje toplinskih svojstava tih ploča.

Ključne riječi: cementom vezana iverica (CBPB); plovućac; plastifikator; fizička i mehanička svojstva; toplinska vodljivost

\section{INTRODUCTION}

\section{UVOD}

Today, the concept of waste management has gained substantial impetus due to limited natural resources and increasing world population. This concept is a leading research topic for renewable chemical resources and converting waste into raw materials to be used for value-added products (Dziurka, 2013; Cavdar et al., 2013). To cope with the scarcity of timber production, it is necessary to develop new solutions. One of the solutions provided by engineering technology that can be implemented today is that the lesser known wood species or timber waste can be converted into wood products such as particleboard, fiberboard, oriented strand board (OSB), wood-cement board or other wood composite materials (Gunawan, 2012).

One of the composite materials produced from wooden materials is cement-bonded particleboards (CBPBs). CBPBs are made of particles, fiber or strands of wood mixed with Portland cement and small quantities of additives manufactured into panels, tiles, bricks, wall elements and other products used in the construction and building industry (Okino et al., 2004; Ashori et al., 2012). CBPBs have a great number of advantages compared to panels produced with organic resins: fire resistance, high resistance to fungal and insect attack, dimensional stability against external weather conditions (Quiroga et al., 2016). The wood composite panels, such as fiberboard and particleboard composites, can be degraded by biological factors and environmental conditions (Reinprecht, 2016).

Pumice has been a well-known lightweight aggregate for over 2000 years due to its resistance and durability. Pumice aggregates, blended with Portland cement and water, can be used in manufacturing of different engineered materials such as insulating structural floor decks, lightweight thermal and sound insulating panels, fire-resistant lightweight concrete for roof decks, lightweight floor fills, shear wall systems, masonry blocks and a variety of other permanent insulating practices (Failla, 1982; Gunduz, 2008). There are about 18 billion tons of pumice deposits in the world. Pumice deposits in Turkey are approximately 15.8 of the total world deposits (Elmastas, 2012). With the use of pumice powder in the cement, it provides heat and sound insulation due to its porous structure. In addition, it increases the resistance properties (El-Gamal and Hashem, 2017).

Normal plasticizers are generally based on lingosulphonate. This is a natural water-soluble organic polymer found in wood and extracted as a waste stream during paper pulp processing. It can be used to give the product higher resistance, to reduce water content for increased strength and reduced permeability, improved durability in order to reduce the amount of cement required to produce a concrete of specified strength and durability and as a cement dispersant at the same water content to increase consistence and workability retention (Akman, 1996).

Pumice powder (PuP) and normal plasticizers (NoP) are important production components for concrete producers. However, there is no comprehensive study related to their effects on the properties of CBPBs. The objective of this study is to investigate the effect of PuP and NoP on some physical and mechanical properties of CBPBs, such as density (D), water absorption (WA), thickness swelling (TS), thermal conductivity (TC), modulus of rupture (MOR), modulus of elasticity (MOE) and internal bond strength (IB).

\section{MATERIALS AND METHODS}

2. MATERIJALI I METODE

\subsection{Materials}

2.1. Materijali

Spruce (Picea orientalis L.) planer shavings were supplied by a commercial forest products plant in Trabzon, Turkey. In this study, fresh type CEM I 42,5R Portland cement was used as the binding agent. Aluminium sulfate $\left[\mathrm{Al}_{2}\left(\mathrm{SO}_{4}\right)_{3} \cdot 18 \mathrm{H}_{2} \mathrm{O}\right]$ and sodium silicate $\left(\mathrm{Na}_{2} \mathrm{SiO}_{2}\right)$ were used as cement curing accelerator. Pumice powder with grain size of $10 \mu \mathrm{m}$ was purchased from BEKTAS mining, Co, Turkey. PLASTIBERG-4000BV Normal plasticizer, provided by Bauberg Co, Germany, was used as the plasticizer. The technical specifications of the plasticizer used are given in Table 1.

\subsection{Methods}

2.2. Metode

\subsubsection{Manufacture of boards}

\subsubsection{Proizvodnja ploča}

Planer shavings were converted into particles using a drum knife flaking machine. Then, they were categorized by means of a horizontal screen shaker. The particles that remained between 3-1.5 mm sieves and

Table 1 Technical specifications of plasticizer

Tablica 1. Tehnička svojstva plastifikatora

\begin{tabular}{|l|c|}
\hline $\begin{array}{l}\text { Structure of material } \\
\text { Struktura materijala }\end{array}$ & $\begin{array}{c}\text { Lignin-based } \\
\text { na bazi lignina }\end{array}$ \\
\hline Color / Boja & Brown / smeđa \\
\hline Density / Gustoća & $1.13-1.16 \mathrm{~kg} / \mathrm{m}^{3}$ \\
\hline $\begin{array}{l}\text { Chlorine }\left(\mathrm{Cl}_{2}\right) \text { content } \\
\text { Sadržaj klora }\left(\mathrm{Cl}_{2}\right)\end{array}$ & $<0.1 \%$ \\
\hline Alkali content / Alkalni sadržaj & $<10 \%$ \\
\hline
\end{tabular}


between $1.5-0.5 \mathrm{~mm}$ sieves were operated in the core and surface sections of the panels, respectively. NoP of $0 \%, 0.4 \%, 0.8 \%$, and $1.2 \%$ were used as substitutes for cement, and PuP of $0 \%, 10 \%, 20 \%$, and $30 \%$ were used as substitutes for particles. A mass ratio of $1 / 2.75$ for wood-cement, and a mass ratio of $1 / 1.64$ for water-cement (the amount of water in the wood strands was included) were used for all the boards. Based on cement weight, $1.5 \%$ aluminium sulfate and $1.75 \%$ sodium silicate were used as additive. Sodium silicate (water-glass) is added to the mixture to accelerate the setting of Portland cement and reduce the volume changes in wood. They penetrate into the capillaries of the wood, where in the course of chemical reactions they turn into insoluble compounds and build up in the wood. This makes access to water more difficult and improves the resistance to swelling and absorbability.

The particles were placed in the mixing vessel and then the calculated amounts of additives and water were added and thoroughly mixed. After that, Portland cement was added and mixing continued until uniformity was obtained. Hand-made board mats with dimensions of $550 \mathrm{~mm} \times 550 \mathrm{~mm} \times 10 \mathrm{~mm}$ were hot pressed for $8 \mathrm{~h}$ and cold pressed for $16 \mathrm{~h}$ to achieve a target board density of $1.200 \mathrm{~g} / \mathrm{cm}^{3}$. Pressing pressure and temperature were selected as $1.8-2 \mathrm{~N} / \mathrm{mm}^{2}$ and $60{ }^{\circ} \mathrm{C}$, respectively. All the boards were designed to have a particle ratio of $40 \%$ at the surface layers and $60 \%$ at the core layer. A total of sixteen experimental panels were manufactured. After pressing, the boards were further stored in a climate room for 28 days at $25{ }^{\circ} \mathrm{C}$ and $65 \% \mathrm{RH}$.

\subsubsection{Physical and mechanical properties}

2.2.2. Fizička i mehanička svojstva ploča

Physical properties including D, WA and TS were determined according to EN 323:1993, ASTM D1037:1998, EN 317:1993, respectively. Mechanical properties including MOR, MOE, and IB were determined according to EN 310:1993, EN 319:1993, respectively using a Zwick 10KN Universal Testing Machine (Zwick Inc. Germany). The results obtained were evaluated according to EN 634-2:2009.

\subsubsection{Thermal conductivity}

\subsubsection{Toplinska vodljivost}

TC analysis of the samples was performed according to ASTM C1113-99:2004 standard by using a thermal conductivity meter (QTM 500-Kyoto Electronic). Thermal conductivity $(\lambda)$ was calculated using the following Eq. 1:

$$
\lambda=\frac{q \cdot \ln \left(t_{2} / t_{1}\right)}{4 \cdot \pi \cdot\left(T_{2}-T_{1}\right)}
$$

Where $\lambda$ is the thermal conductivity coefficient $(\mathrm{W} / \mathrm{mK}), q$ is the heat transfer rate $(\mathrm{cal}), t_{2} / t_{1}$ is the time interval (s) and $T_{2}-T_{1}$ is the temperature difference between the ends $\left({ }^{\circ} \mathrm{C}\right)$.

\subsubsection{Statistical analysis
2.2.4. Statistička analiza}

The result of each cement-bonded particleboard was analyzed with ANOVA test using SPSS 13.0 software. The significance $(p<0.05)$ between the treatments was compared with DUNCAN homogeneity groups.

\section{RESULTS AND DISCUSSION} 3. REZULTATI I RASPRAVA

\subsection{Physical properties}

3.1. Fizička svojstva

The evulation results of physical properties for all the board groups, including homogeneity group values, are shown in Figure 1 and Table 2. Utilization of $\mathrm{PuP}$ and NoP were found to be effective on the amount of WA. Using a PuP of $30 \%$ provided a $12 \%$ reduction in WA values compared to the control group. Based on EN standards, cement-bonded particleboards should have a maximum TS value of $1.5 \%$, for 24 hours immersion (EN 634-2, 2009). Generally, an increasing amount of PuP resulted in a decrease in WA and TS values. This decrease may be attributed to the fact that PuP has a lesser hydrophilic character than wood raw material. Sarışık and Sarışık (2010) reported that the pumice water absorption rate was determined as $34 \%$. Kılıç and Hafizoglu (2002) determined that WA values of poplar, fir, pine and alder were $95 \%, 139 \%, 100 \%$, and $81 \%$ in their study on a variety of wood samples to determine the rate of water uptake of wood species kept in water for 48 hours, respectively. So, a decrease in the use of wood chips has increased the water resistance of the boards.

The amount of plasticizer affected WA and TS values of the boards. Using $0.4 \%$ and $0.8 \%$ plasticizer

Table 2 Homogeneity groups of properties depending on pumice powder and plasticizer amount

Tablica 2. Homogenost grupa svojstava ovisno o količini praha plovućca i plastifikatora

\begin{tabular}{|c|c|c|c|c|c|c|c|c|}
\hline $\begin{array}{l}\text { Source of parameter } \\
\text { Izvor parametra }\end{array}$ & $\begin{array}{l}\text { Content } \\
\text { Sadržaj }\end{array}$ & $\begin{array}{c}\boldsymbol{D} \\
\mathrm{g} / \mathrm{cm}^{3}\end{array}$ & $\begin{array}{c}W A \\
\%\end{array}$ & $\begin{array}{l}T S \\
\%\end{array}$ & $\begin{array}{c}\boldsymbol{T C} \\
\mathrm{W} / \mathrm{mK}\end{array}$ & $\begin{array}{c}\text { MOR } \\
\mathrm{N} / \mathrm{mm}^{2}\end{array}$ & $\begin{array}{c}\text { MOE } \\
\mathrm{N} / \mathrm{mm}^{2}\end{array}$ & $\begin{array}{c}\boldsymbol{I B} \\
\mathrm{N} / \mathrm{mm}^{2}\end{array}$ \\
\hline \multirow{5}{*}{$\mathrm{PuP}(\%)$} & & $\mathrm{HG}$ & $\mathrm{HG}$ & $\mathrm{HG}$ & $\mathrm{HG}$ & HG & HG & HG \\
\hline & 0 & $\mathrm{~A}^{*}$ & $\mathrm{~A}$ & $\mathrm{~A}$ & $\mathrm{~A}$ & $\mathrm{~A}$ & $\mathrm{~A}$ & $\mathrm{~A}$ \\
\hline & 10 & $\mathrm{~A}$ & $\mathrm{~B}$ & $\mathrm{~A}$ & $\mathrm{~A}$ & $\mathrm{AB}$ & $\mathrm{B}$ & $\mathrm{B}$ \\
\hline & 20 & A & $\mathrm{C}$ & $\mathrm{B}$ & $\mathrm{A}$ & $\mathrm{B}$ & $\mathrm{C}$ & $\mathrm{C}$ \\
\hline & 30 & A & $\mathrm{D}$ & $\mathrm{C}$ & B & B & $\mathrm{D}$ & $\mathrm{D}$ \\
\hline \multirow{4}{*}{$\mathrm{NoP}(\%)$} & 0 & $\mathrm{~A}$ & $\mathrm{~A}$ & $\mathrm{~A}$ & $\mathrm{~A}$ & $\mathrm{~A}$ & $\mathrm{~A}$ & $\mathrm{~A}$ \\
\hline & 0.4 & A & B & B & $\mathrm{A}$ & B & B & B \\
\hline & 0.8 & $\mathrm{~A}$ & $\mathrm{~B}$ & $\mathrm{~B}$ & $\mathrm{~B}$ & $\mathrm{~A}$ & $\mathrm{C}$ & $\mathrm{C}$ \\
\hline & 0.12 & A & $\mathrm{C}$ & $\mathrm{C}$ & B & $\mathrm{C}$ & $\mathrm{D}$ & $\mathrm{D}$ \\
\hline
\end{tabular}

*Different letters mean that there is a significant difference. / Različito slovo označava postojanje značajne razlike. 

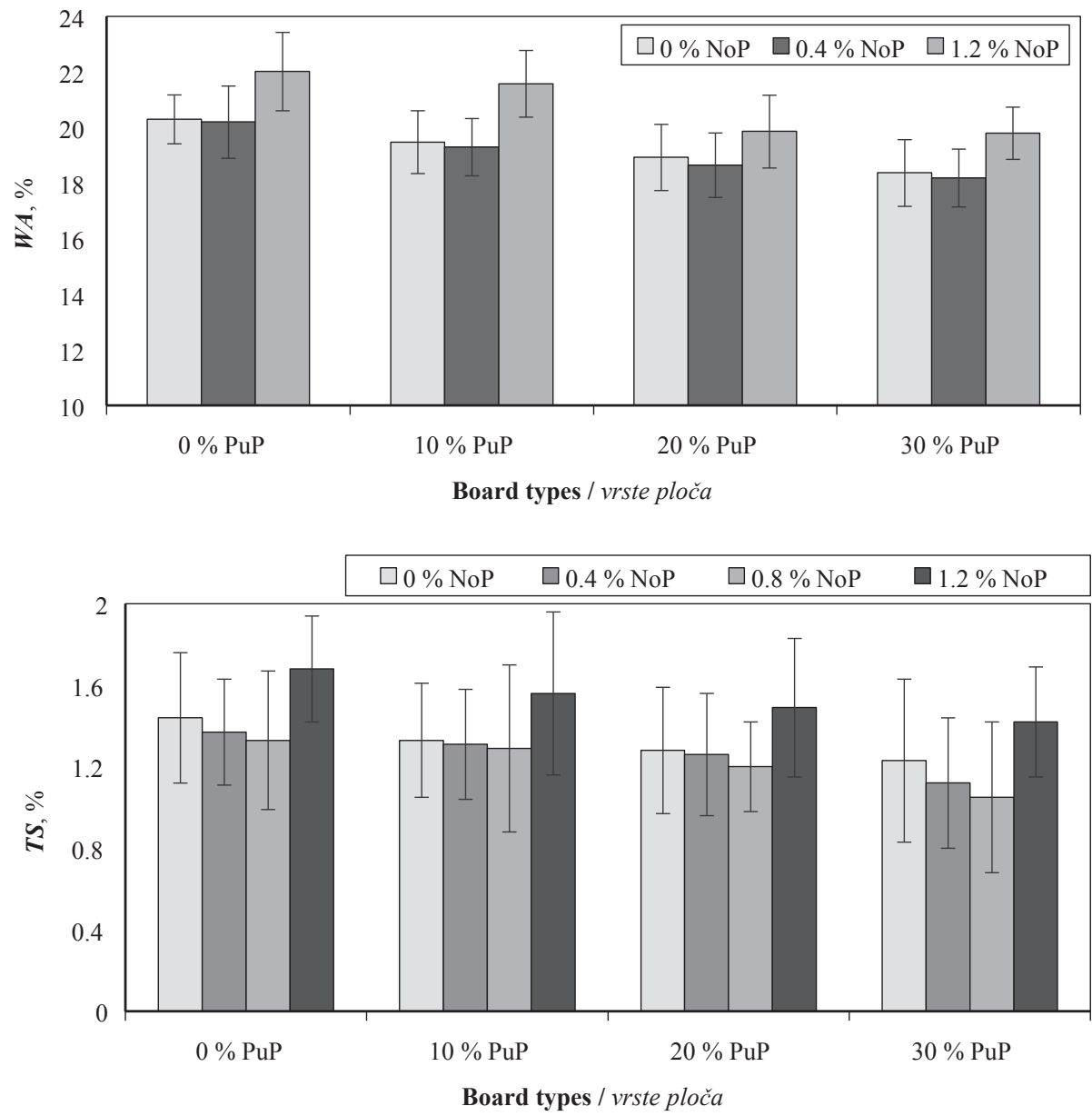

Figure 1 The effect of the amount of PuP and NoP on dimensional stability of boards Slika 1. Utjecaj količine PuP-a i NoP-a na dimenzijsku stabilnost ploča

increased the resistance of the boards to water. The plasticizers act as an air-entraining agent in the concrete. In addition, they prevent cement grains from sticking together and caking (Uyan and Akman, 1985). This increases the impact strength and toughness properties of the boards. On the other hand, using $1.2 \%$ plasticizer decreased the water resistance of the boards. This is caused by the failure of holding together the mixture of solid particles. Thus, the concrete loses stability, and separations occur (Turkel and Felekoglu, 2004). Therefore, the excessive use of plasticizer adversely affected the board properties.

\subsection{Mechanical properties}

\subsection{Mehanička svojstva}

The results of mechanical properties for all the board groups, including homogeneity group values, are shown in Figure 2 and Table 2. The mechanical properties of the boards gave results in accordance with the standard EN 634-2 (2009), except for those using 1.2 $\%$ NoP. The use of $1.2 \%$ NoP resulted in a reduction of $5 \%$ in MOR compared to the control group. Moslemi and Prifister (1987) stated that there is a significant relationship between wood-cement ratio and bending resistance. Suitable ratios for high bending resistance values are between $1 / 2$ and $1 / 3$. The wood-cement ratio increased to $1 / 4$ when a PuP of $30 \%$ was used. Thus, reducing the amount of wood may have caused the bending resistance to decrease. The applied force spreads over a larger area with the increase in the amount of wood. This leads to a decrease in tension and has a positive effect on bending resistance (Papadopoulos et al., 2006).

The use of over-plasticizer reduced the MOR values. There is a certain dosage range for the use of the plasticizer. The use of plasticizers in excess of this range can cause some problems such as delay and shortening of the cement setting, early reduction and decomposition (Ferraris, 1999; Halim et al., 2017). The plasticizer dosage range according to the concrete institute varies between $0.25 \%$ and $0.45 \%$ (CI, 2013). Especially, the chemical structure and physical properties of the cement used in production have a significant impact on the utilization rate (Tkaczewska et al., 2014). Besides, the addition of wood particles in the cement paste may have affected this rate.

When the effect of the amount of pumice powder on MOE was examined, the result showed that it had a negative linear relationship with MOE. Adding a PuP of $30 \%$ to the board leads to an improvement of $20 \%$ in its MOE values. Decrease in wood-cement ratio leads to an increase in MOE (Frybort et al., 2008). Papadopoulos et al. (2008) reported that a change in the wood-cement ratio from $1 / 3$ to $1 / 4$ decreased MOR by approximately $20 \%$, while it increased MOE by about $15 \%$. The highest MOE values were obtained with the 

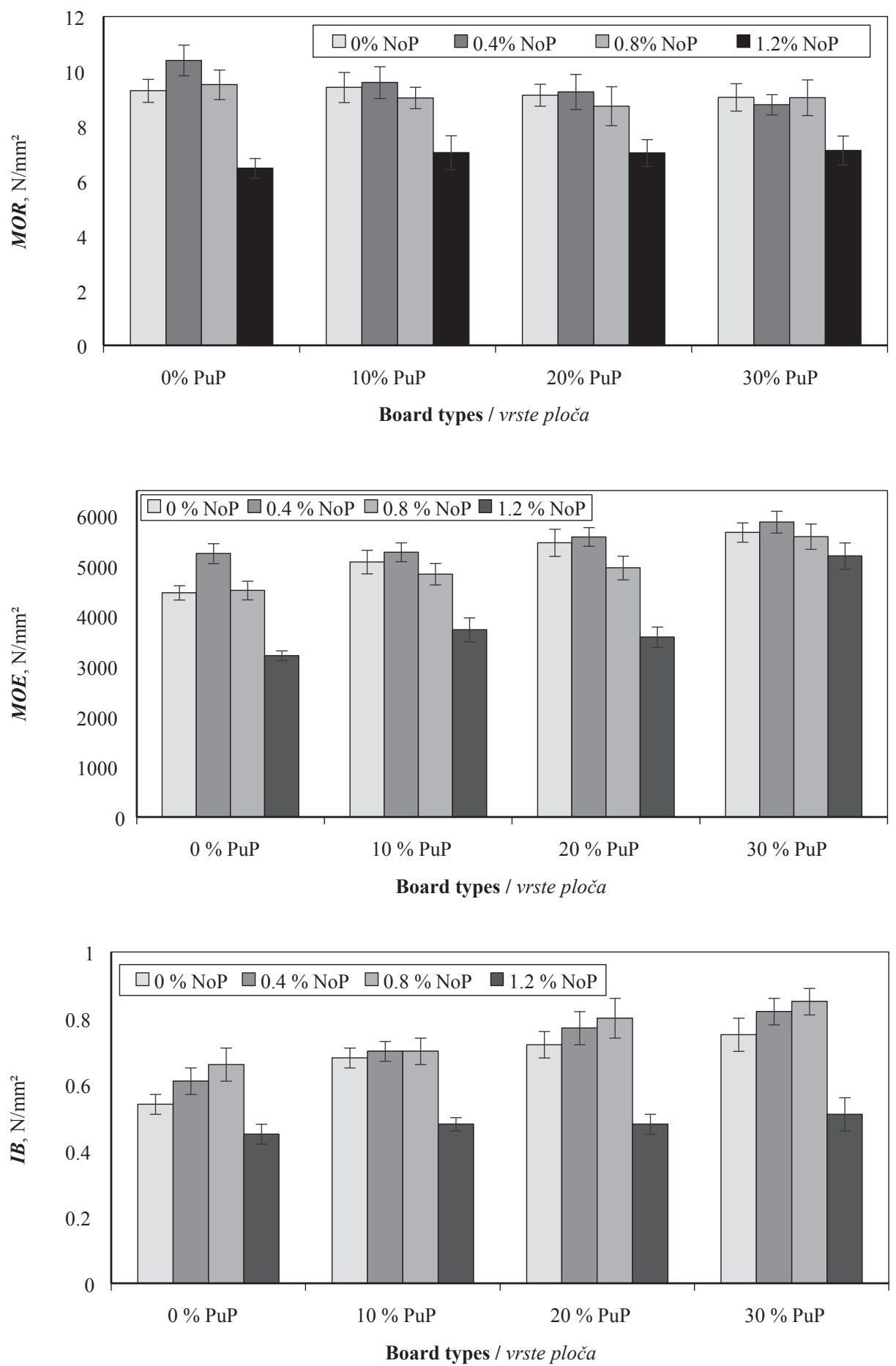

Figure 2 The effect of the amount of PuP and NoP on mechanical properties of boards Slika 2. Utjecaj količine PuP-a i NoP-a na mehanička svojstva ploča

use of $4 \%$ plasticizer. Studies have shown that the use of plasticizers improves the consistency and performance of concrete (Burgos et al., 2012, Topcu et al., 2016).

The results demonstrated that using a PuP of 30 $\%$ provided an improvement of $20 \%$ in the IB strength of the boards. PuP shows pozzolan properties due to the high content of amorphous silica. The inhibited effect of wood extractives is reduced by adding pozzolanic additives in cement based wood composites (Vaickelionis and Vaickelioniene, 2006). PuP contributed to a reduction in the concentration of water and alkaline soluble components, which inhibited the hydration re- action of cement, in wood-cement paste because it was used instead of wood. This may have positively affected the hydration of cement.

\subsection{Thermal conductivity}

3.3. Toplinska vodljivost

The results of thermal conductivity for all the board groups, with homogeneity group values, are shown in Figure 4 and Table 2. According to the results, the boards produced cannot be accepted as thermal insulation materials. Nonetheless, the positive effects on the insulation of the construction can be examined. 


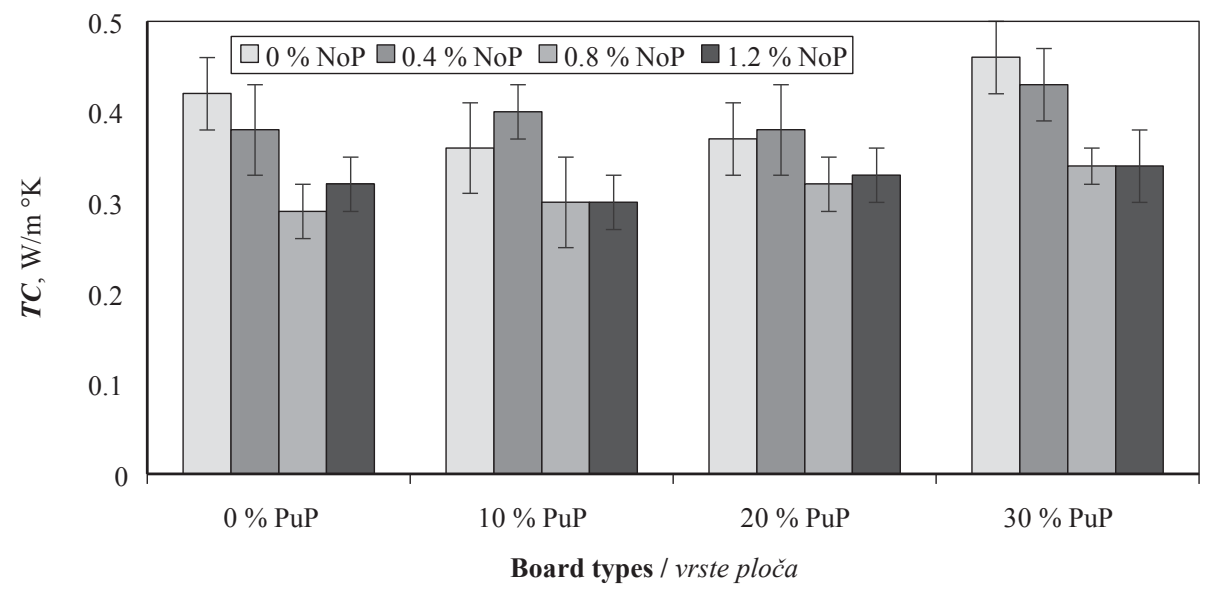

Figure 3 The effect of the amount of PuP and NoP on thermal conductivity of boards Slika 3. Utjecaj količine PuP-a i NoP-a na toplinsku vodljivost ploča

The TC values increased by $15 \%$ as the amount of PuP increased only up to $30 \%$. It can be said that the amount of voids decreased and heat transfer increased due to the reduction in particle size. Therefore, the decrease in the amount of wood use increased the heat transfer coefficient because wood is a good heat insulation material since it contains empty spaces (Ross, 2010). Bederina and Quéneudec (2010) reported that the addition of wood shavings in concrete improves its thermal insulation properties. The increase in the amount of NoP leads to a decrease in the heat-conducting properties of the boards. The TC values decreased by $18 \%$ as the amount of NoP increased to $1.2 \%$. It can be said that the use of plasticizers also improves the thermal insulation properties due to the positive effect on the flow and placement of cement. The use of plasticizers increases both the fluidity of the cement paste and the amount of adsorption to the cement fraction of the plasticizer (Zhang et al., 2016).

\section{CONCLUSIONS \\ 4. ZAKLJUČAK}

In this study, the effects of PuP and NoP on the physico-mechanical properties and thermal conductivity of CBPBs were investigated. In general, $0.4 \%$ and $0.8 \%$ NoP improved the dimensional stability and mechanical resistance properties of the boards. On the contrary, when $1.2 \%$ NoP were used, mechanical resistance properties were negatively affected due to the corruption in the structure of the board. On the other hand, PuP increased the dimensional stability, MOR and IB properties of the boards. However, PuP reduced the bending resistance of the boards. Although the TC values of the boards are compatible with the studies conducted under similar conditions, it has been determined that they will not be used as thermal insulation material. Even though $1.2 \%$ NoP decreased the strength properties of the boards, it reduced the thermal conductivity coefficient. It was concluded that the use of PuP and NoP at the appropriate dosage improved the strength properties of CBPBs. Additionally, there is potential in the use of planer shavings as an alternative to wood material as reinforcement in wood cement composites for building construction helping in reducing waste disposal costs.

\section{REFERENCES}

\section{LITERATURA}

1. Akman, M. S., 1998: Problems of superplasticizer admixtures processing of fresh concrete. Proceeding of 4th National Concrete Congress, October 30 1998., Istanbul, Turkey, pp. 55-71.

2. Alpár, T.; Rácz, I., 2009: Production of cement-bonded particleboards from poplar (Populus euramericana cv. „I 214“). Drvna industrija, 60 (3): 155-160.

3. Ashori, A.; Tabarsa, T.; Sepahvand, S., 2012: Cementbonded composite boards made from poplar strands. Construction and Building Materials, 26 (1): 131-134. https://doi.org/10.1016/j.conbuildmat.2011.06.001.

4. Bederina, M.; Quéneudec, M., 2010: Characterization of River-Dune Sand Concrete Lightened by Addition of Wood Shavings. In Second international conference on sustainable construction materials and technologies, June 28 2010, Ancona, Italy, pp. 28-30.

5. Burgos-Montes, O.; Palacios, M.; Rivilla, P.; Puertas, F., 2012: Compatibility between superplasticizer admixtures and cements with mineral additions. Construction and Building Materials, 31: 300-309.

https://doi.org/10.1016/j.conbuildmat.2011.12.092.

6. Cavdar, A. D.; Yel, H.; Kalaycioglu, H.; Salim, H., 2013. Effect of waste melamine impregnated paper on properties of oriented strand board. Material Design, 51 (1): 751-755. https://doi.org/10.1016/j.matdes.2013.04.052.

7. Dziurka, D.; Mirski, R., 2013: Lightweight boards from wood and rape straw particles. Drewno, 56 (190): 19-31. https://doi.org/10.12841/wood.1644-3985.051.02.

8. Elmastas, N., 2012: A mine becoming increasingly important or economy of turkey: pumice. The Journal of International Social Research, 5 (23): 197-206.

9. Failla, A.; Mancuso, P.; Miraglia, N.; Ruisi, V., 1982: Experimentaltheoretical study on pumice aggregate lightweight concrete. Technical Report, The Instuto di Scienza delle Costrurioni. Facolta di Ingegneria, Palermo; Ministero delta Publica Instuzione, Palermo, pp. 3-22.

10. Ferraris, C. F., 1999: Measurement of the rheological properties of high performance concrete: state of the art report. Journal of the National Institute of Standards and Technology, 104 (2): 461-478. 
11. Frybort, S.; Mauritz, R.; Teischinger, A.; Muller, U., 2008: Cement bonded composites - a mechanical review. BioResources, 3 (2): 602-626.

12. El-Gamal, S. M.; Hashem, F. S., 2017: Enhancing the thermal resistance and mechanical properties of hardened Portland cement pastes by using pumice and $\mathrm{Al} 2 \mathrm{O} 3$. Journal of Thermal Analysis and Calorimetry, 128 (1): 15-27. https://doi.org/10.1007/s10973-016-5863-2.

13. Gunawan, E.; Adhyaksa, A. I.; Cabuy, R. L., 2012: Influence of sawdust size and ratio of HDPE waste on the physical properties of wood-plastics composite. International Journal of Basic and Applied Sciences, 12 (4): 38-42.

14. Gunduz, L., 2008: The effects of pumice aggregate/cement ratios on the low strength concrete properties. Cement and Concrete Composites, 22 (1): 721-728. https://doi.org/10.1016/j.conbuildmat.2007.01.030.

15. Halim, J. G.; Kusuma, O. C.; Hardjito, D., 2017: Optimizing polycarboxylate based superplasticizer dosage with different cement type. Procedia Engineering, 171: 752-759. https://doi.org/10.1016/j.proeng.2017.01.442.

16. Kılıç, A.; Hafizoglu, H., 2002: Enrichment of dimensional stability in some wood species treated with methyl methacrylate. Zonguldak Karaelmas University Journal of Faculty of Forestry, 4 (4): 20-27.

17. Moslemi, A. A.; Pfister, S. C., 1987: The influence of cement/wood ratio and cement type on bending strength and dimensional stability of wood-cement composite panels. Wood Fiber Science, 19: 165-175.

18. Okino, E. Y. A.; De Souza, M. R.; Santana, M. A. E.; Alves, M. S.; De Souza, M. E.; Teixeria, D. E., 2004: Cement-bonded wood particleboard with a mixture of eucalypt and rubberwood. Cement and Concrete Composites, 26 (6): 729-734. https://doi.org/10.1016/S0958-9465(03)00061-1.

19. Papadopoulos, A. N., 2008: Natural durability and performance of hornbeam cement bonded particleboard. Maderas Ciencia y tecnología, 10 (2): 93-98. https://doi.org/10.4067/S0718-221X2008000200002.

20. Papadopoulos, A. N.; Ntalos, G. A.; Kakaras, I., 2006: Mechanical and physical properties of cement-bonded OSB. Holz als Roh- und Werkstoff, 64: 517-518. https://doi.org/10.1007/s00107-005-0092-6.

21. Quiroga, A.; Marzocchi, V.; Rintoul, I., 2016: Influence of wood treatments on mechanical properties of woodcement composites and of Populus Euroamericana wood fibers. Composites Part B: Engineering, 84: 25-32. https://doi.org/10.1016/j.compositesb.2015.08.069.

22. Reinprecht, L., 2016: Wood Deterioration, Protection and Maintenance. Chapter 3: Biological Degradation of Wood. John Wiley and Sons, Ltd., Oxford, UK.

23. Ross, R. J., 2010: Wood handbook: wood as an engineering material. General Technical Report (GTR). Forest Products Laboratory, Forest Service, USDA.

24. Sarışık, A.; Sarışık G., 2010: Production of pumice aggregate lightweight concrete and eps foam insulation block, their compliance with the standards and comparison with other masonry materials. Scientific Mining Journal, 49 (2): 27-39.

25. Tkaczewska, E., 2014: Effect of the superplasticizer type on the properties of the fly ash blended cement. Construction and Building Materials, 70: 388-393. https://doi.org/10.1016/j.conbuildmat.2014.07.096.
26. Topçu, I. B.; Ateşin, O., 2016: Effect of high dosage lignosulphonate and naphthalene sulphonate based plasticizer usage on micro concrete properties. Construction and Building Materials, 120: 89-197.

https://doi.org/10.1016/j.conbuildmat.2016.05.112.

27. Turkel, S.; Felekoglu, B., 2004: The effect of the use of excessive dosages of chemical plasticizer on some properties of fresh and hardened concrete. Dokuz Eylul University Faculty of Engineering Journal of Science and Engineering, 6 (1): 77-89.

28. Uyan, M.; Akman, S., 1985: Influence of set accelerators and a water reducing admixture on the properties of atmospheric pressure steam cured concrete. The Joint Seminar ACI-RILEM, 10-15 March 1985. Monterrey, N.L., Mexico.

29. Vaickelionis, G.; Vaickelioniene, R., 2006: Cement hydration in the presence of wood extractives and pozzolan mineral additives. Ceramics-Silikaty, 50 (2): 115-122.

30. Zhang, G.; Li, G.; Li, Y., 2016: Effects of superplasticizers and retarders on the fluidity and strength of sulphoaluminate cement. Construction and Building Materials, 126: 44-54. https://doi.org/10.1016/j.conbuildmat.2016.09.019.

31. ***ASTM C1113-99, 2004: Standards test methods for thermal conductivity of refractories by hot wire (platinum resistance thermometer technique).

32. ***ASTM D1037, 1998: Standard Test Method for Evaluating Properties of Wood-Base Fiber and Particle Panel Materials.

33. ***CI, 2013: Admixtures for concrete. The Concrete Institute, Midland. https://docs.wixstatic.com/ugd/5586b6 cef1571f757d43b6a328bbfbece5cf64.pdf (Accessed $1 \overline{5}$ Jun, 2017).

34. ***EN 113, 1997: Method of test for determining the protective effectiveness against wood rotting basidiomycetes-determination of toxic values.

35. ****EN 310, 1993: Wood based panels, determination of modulus of elasticity in bending and bending strength.

36. ${ }^{* * *}$ EN 317, 1993: Particleboards and fiberboards, determination of swelling in thickness after immersion.

37. ***EN 319, 1993: Particleboards and fiberboards, determination of tensile strength perpendicular to plane of the board.

38. ***EN 323, 1993: Wood-based panels. Determination of density.

39. ***EN 634-2, 2009: Cement-bonded particleboards Specifications - Part 2: Requirements for OPC bonded particleboards for use in dry, humid and external conditions.

\section{Corresponding address:}

\section{UGUR ARAS}

Karadeniz Technical University

Arsin Vocational school

Department of Material and Material Processing

Technologies

61900, Trabzon, TURKEY

e-mail: uguraras.86@gmail.com 